\title{
Phoenixin and nesfatin-1 - novel neuropeptides in anxiety disorders
}

\author{
Feniksyna i nesfatyna-1 - nowe neuropeptydy w zaburzeniach lękowych
}

\author{
1 Department of Histology, School of Medicine in Katowice, Medical University of Silesia, Katowice, Poland \\ 2 Department of Histology and Embryology, School of Medicine with Division of Dentistry in Zabrze, Medical University of Silesia, Zabrze, Poland \\ ${ }^{3}$ Clinical Ward of Developmental Age Psychiatry and Psychotherapy of the Department of Psychiatry and Psychotherapy, Medical University of Silesia, Katowice, Poland \\ ${ }^{4}$ Private Psychotherapy Practice"Relation,"Sosnowiec, Poland \\ ${ }^{5}$ Paediatric Centre of John Paul II in Sosnowiec sp. z 0.0., Sosnowiec, Poland \\ Correspondence: Artur Pałasz, Department of Histology, School of Medicine in Katowice, Medical University of Silesia, Medyków 18, 40-752 Katowice, Poland, e-mail: apalasz@sum.edu.pl
}

'Zakład Histologii, Wydział Lekarski w Katowicach, Śląski Uniwersytet Medyczny, Katowice, Polska

${ }^{2}$ Katedra i Zakład Anatomii Opisowej i Topograficznej, Wydział Lekarski w Zabrzu, Śląski Uniwersytet Medyczny, Zabrze, Polska

${ }^{3}$ Oddział Kliniczny Psychiatrii i Psychoterapii Wieku Rozwojowego, Katedra Psychiatrii i Psychoterapii, Wydział Lekarski w Katowicach, Śląski Uniwersytet Medyczny, Katowice, Polska

${ }^{4}$ Prywatny Gabinet Psychoterapii, Relacja", Sosnowiec, Polska

${ }^{5}$ Centrum Pediatrii im. Jana Pawła II w Sosnowcu sp. Z 0.0., Sosnowiec, Polska

Adres do korespondencji: Artur Pałasz, Zakład Histologii, Wydział Lekarski w Katowicach, Śląski Uniwersytet Medyczny, ul. Medyków 18, 40-752 Katowice, e-mail: apalasz@sum.edu.pl

Abstract Anxiety disorders are the most common mental health conditions and currently constitute a significant social and pharmacological issue. The neurochemical aetiology of anxiety has not been fully explained yet, and it has been the subject of numerous basic research studies. In this context, the recently identified highly multifunctional regulatory neurohormones phoenixin and nesfatin-1 seem to be of special interest. Phoenixin, a neuropeptide of hypothalamic-pituitary-gonadal axis, has potent anxiolytic properties in the animal model. Newly identified hypothalamic and brainstem neuropeptide nesfatin-1 is considered to play an important role in the mechanisms underlying generation of anxiety symptoms in animals. Clinical studies showing decreased serum levels of nesfatin-1 in patients with generalised anxiety disorder are sparse. On the other hand, elevated nesfatin-1 expression was noted in the brainstem of male suicide victims. The neurophysiological effects of both nesfatin-1 and phoenixin seem to be distinctly sex-related. The aim of this review article is to summarise recent reports regarding the postulated involvement of these neuropeptides in the functioning of neuronal pathways involved in the pathophysiology of anxiety responses.

Keywords: nesfatin-1, phoenixin, anxiety, hypothalamus, neuropeptides

Streszczenie Zaburzenia lękowe, należące do najczęściej występujących dysfunkcji psychicznych, stanowią obecnie istotny problem społeczny i farmakologiczny. Neurochemiczne podłoże lęku nie zostało jeszcze w pełni wyjaśnione i jest przedmiotem licznych badań podstawowych. Wydaje się, iż czynnikami szczególnie wartymi uwagi są niedawno zidentyfikowane wysoce wielofunkcyjne neurohormony regulatorowe mózgu: feniksyna i nesfatyna-1. Feniksyna, neuropeptyd osi podwzgórzowo-przysadkowo-gonadalnej, manifestuje silne efekty anksjolityczne w modelu zwierzęcym. Nesfatyna-1, opisany w ostatnich latach neuropeptyd podwzgórza i pnia mózgu, prawdopodobnie odgrywa ważną rolę w mechanizmach generowania ogólnych objawów stresu i reakcji lękowych u zwierząt. Nieliczne dane kliniczne wykazały spadek stężenia nesfatyny-1 u pacjentów płci męskiej z uogólnionymi zaburzeniami lękowymi. Zarazem jednak odnotowano istotnie zwiększoną ekspresję nesfatyny-1 w pniu mózgu mężczyzn zmarłych w wyniku samobójstwa. Efekty neurofizjologiczne zarówno nesfatyny-1, jak i feniksyny wydają się wybitnie zależne od płci. Celem niniejszej pracy poglądowej jest podsumowanie najnowszych doniesień na temat postulowanego udziału wymienionych neuropeptydów w funkcjonowaniu szlaków neuronalnych związanych z patofizjologią reakcji lękowych.

Słowa kluczowe: nesfatyna-1, feniksyna, lęk, podwzgórze, neuropeptydy 


\section{NEUROPEPTIDES IN THE PATHOGENESIS OF ANXIETY}

A nxiety disorders are currently the most widespread mental dysfunctions (Stein et al., 2017). For a long time, neuropeptides have been believed to be the factors engaged in anxiety regulation. The family of corticotropin-releasing factors (CRF) composed of CRF and urocortins (Ucn) 1, 2 and 3 is a key component of the hypothalamus-pituitary-adrenal axis (HPA), a system of a key role in the physiological response to stress (Kormos and Gaszner, 2013). Oxytocin (OT) and arginine vasopressin (AVP) are well-known regulators of anxiety and response to stress, by acting both on the HPA axis and via independent mechanisms. AVP acts synergistically with CRF at the level of the pituitary gland (Knepel et al., 1984). Oxytocin inhibits CRF synthesis in the paraventricular nucleus (Jurek et al., 2015), but it increases the adrenocorticotropic hormone $(\mathrm{ACTH})$ release as a response to CRF at the level of the pituitary gland (Gibbs et al., 1984). The neuropeptide S (NPS), a multifunctional regulatory factor of the brainstem, seems to be yet another important player in the mechanism of anxiety (Slattery et al., 2015). Behavioural studies show that administration of NPS induces a strong dopaminerelated anxiolytic activity in rats (Lucas et al., 2014; Si et al., 2010). Furthermore, NPS injection to the mouse amygdala decreases conditioned anxiety levels (Jungling et al., 2008). Some clinical studies also suggest that the changes in the NPSR gene may be linked with a stress reaction and increased stimulation in the HPA axis (Kumsta et al., 2013). Also, orexins may play a key role in the pathogenesis of anxiety (Flores et al., 2015). It was observed that CSF levels of orexins are increased in patients suffering from panic attacks as compared to healthy individuals (Johnson et al., 2010). Recent reports suggest that prolonged stress may increase the number of orexin-A-expressing neurons in the hypothalamus of male mice (Jalewa et al., 2014). On the other hand, a recent research incorporating the DREADD method based on construing receptors activated solely by exogenous ligands suggests that OX2R may be involved in generating acute responses to stress in male rats and may reduce the habit of recurring stress at a high level of orexins (Grafe et al., 2017).

\section{PHOENIXIN AS A POTENTIAL ANXIOLYTIC FACTOR}

Phoenixin (PNX) is a newly identified, endogenous, regulatory neuropeptide of the brain which exists in two active molecular isoforms: PNX-14 and PNX-20. For various species of vertebrates, both are extremely conserved products of posttranslational processing of the prohormone SMIM20. PNX may have an effect on releasing gonadotropin from the pituitary gland through the modulation of gonadotropin receptor (GnRH-R) expression.

\section{NEUROPEPTYDY W PATOGENEZIE LĘKU}

$\mathrm{Z}$ aburzenia lękowe są obecnie najbardziej rozpowszechnionymi dysfunkcjami psychicznymi (Stein et al., 2017), a neuropeptydy od dawna uważa się za czynniki zaangażowane w regulację lęku. Rodzina czynników uwalniających kortykotropinę (corticotropin-releasing factor, CRF), złożona z CRF oraz urokortyn (Ucn) 1, 2 i 3, jest kluczowym komponentem osi podwzgórze-przysadka-nadnercza (hypothalamus-pituitary-adrenal axis, HPA), systemu o kluczowym znaczeniu dla fizjologicznej reakcji na stres (Kormos i Gaszner, 2013). Oksytocyna (OT) i wazopresyna argininowa (arginine vasopressin, AVP) są dobrze znanymi regulatorami lęku i odpowiedzi na stres; działają zarówno na oś HPA, jak i poprzez niezależne mechanizmy. AVP działa synergistycznie z CRF w celu zwiększenia uwalniania adrenokortykotropiny (ACTH) z przysadki mózgowej (Knepel et al., 1984). Oksytocyna hamuje syntezę CRF w jądrze przykomorowym (Jurek et al., 2015), ale wzmaga uwalnianie ACTH w odpowiedzi na CRF na poziomie przysadki (Gibbs et al., 1984). Neuropeptyd S (NPS), wieloczynnościowy czynnik regulatorowy pnia mózgu, wydaje się kolejnym ważnym czynnikiem w mechanizmie lęku (Slattery et al., 2015). Badania behawioralne na szczurach pokazują, że podawanie NPS działa silnie przeciwlękowo, co wiąże się z sygnalizacją dopaminergiczną (Lucas et al., 2014; Si et al., 2010). Ponadto po wstrzyknięciu NPS do mysiego ciała migdałowatego następuje zmniejszenie uwarunkowanego strachu (Jungling et al., 2008). Niektóre badania kliniczne sugerują również, że zmiany genu NPSR można łączyć z reakcją stresową i zwiększoną stymulacją w osi HPA (Kumsta et al., 2013). Także oreksyny mogą odgrywać ważną rolę w patogenezie lęku (Flores et al., 2015). Zaobserwowano, że pacjenci cierpiący na ataki paniki mieli podwyższony poziom oreksyn w płynie mózgowo-rdzeniowym w porównaniu z osobami zdrowymi (Johnson et al., 2010). Jak wskazują nowe doniesienia, przedłużający się stres może zwiększać liczbę neuronów oreksynergicznych w podwzgórzu myszy (Jalewa et al., 2014). Z kolei najnowsze badanie wykorzystujące technikę DREADD - opartą na konstruowaniu receptorów stymulowanych jedynie egzogennymi ligandami - sugeruje, że receptor OX2R może być zaangażowany w generowanie ostrych odpowiedzi na stres u szczurów (Grafe et al., 2017).

\section{FENIKSYNA JAKO POTENCJALNY CZYNNIK ANKSJOLITYCZNY}

Feniksyna (phoenixin, PNX) jest nowo zidentyfikowanym endogennym neuropeptydem regulatorowym mózgu, występującym w dwóch aktywnych formach molekularnych: PNX-14 i PNX-20. Obie są ewolucyjnie konserwatywnymi produktami potranslacyjnej obróbki prohormonu SMIM20. PNX może wpływać na uwalnianie gonadotropiny z przysadki przez modulację ekspresji receptora gonadotropiny (GnRH-R). Wstępne badania sugerują również, że PNX raczej uwrażliwia przysadkę mózgową na czynniki 
the pituitary gland to the releasing factors and does not directly stimulate hormonal exocytosis from the pituitary gland cells (Yosten et al., 2013). The presence of PNX was identified in limited neuronal populations in the hypothalamus, amygdala, anterior horns of the spinal cord, solitary tract and sensory ganglia (Lyu et al., 2013). The arcuate nucleus contains the population of PNX-expressing kisspeptin neurons (Gottsch et al., 2004), which send their efferents to the gonadotropin $(\mathrm{GnRH})$ cells in the middle preoptic area (Canteras et al., 1994; Simonian et al., 1999). PNX may therefore be a novel hypothalamic regulatory factor which stimulates the activity of gonadotropic cells of the pituitary gland. Hypothetically, PNX may also activate kisspeptin neurons in an autocrine manner and/or through the connection with other PNX-expressing cells (Treen et al., 2016). It should be noted that a great majority of nesfatin neurons in the rat hypothalamic nuclei exhibit PNX expression, which may suggest the existence of potential, so-far unknown functional correlations between these neuropeptides in the brain (Pałasz et al., 2015). PNX is a ligand of metabotropic GPR173, which is strongly expressed in both kisspeptin and GnRH neurons (Treen et al., 2016). GPR173, also known as SREB3, belongs to the super-conserved family of receptors expressed in the brain (SREB), which was detected in the brain and ovaries and may play a key role in the hypothalamic-pituitarygonadal (HPG) axis regulation (Matsumoto et al., 2005). The latest study suggests that GPR173 acts in the hypothalamic neurons through the pathway of the cAMP/A protein kinase by the cAMP response element-binding protein (CREB) and probably DNA damage-inducible transcript 3 $(\mathrm{C} / \mathrm{EBP}-\beta)$ and/or Oct-1 to stimulate the expression of kisspeptin 1 and GnRH (Treen et al., 2016).

Jiang et al. (2015a) showed that PNX-14 acts as a strong anxiety-relieving factor in male mice after central administration. PNX-14 infusion to the lateral ventricle or the anterior hypothalamic area, but not to the amygdala, reduced anxiety-like behaviour in the open field and in the elevated plus maze (EPM) test in adult rodents. Importantly, administration of a selective antagonist of the GnRH receptor (cetrorelix) neutralised the anxiolytic activity of PNX-14. On the other hand, the inhibition of the oxytocin/vasopressin receptors by atosiban did not change this effect. Therefore, it should be assumed that PNX-14 generates an oxytocin-independent anxiety-relieving activity through the stimulation of the GnRH signalling system in the anterior hypothalamus. In their latest clinical study, Hofmann et al. (2017) for the first time investigated the relationship between the PNX peripheral level and anxiety in a large group $(N=68)$ of obese, psychometrically diagnosed (Generalized Anxiety Disorder 7-item, GAD-7), hospitalised male patients. Depressiveness and perceptible stress levels were assessed with the PHQ-9 (Perceived Health Questionnaire) and PSQ-20 (Perceived Stress Questionnaire) scales, respectively. Plasma PNX levels were negatively correlated with uwalniające, aniżeli bezpośrednio stymuluje egzocytozę hormonalną z komórek przysadki mózgowej (Yosten et al., 2013). Obecność PNX zidentyfikowano w ograniczonych populacjach neuronalnych zlokalizowanych w podwzgórzu, ciele migdałowatym, przednich rogach rdzenia kręgowego, paśmie samotnym i zwojach czuciowych (Lyu et al., 2013). Jądro łukowate zawiera populację neuronów kisspeptyny z ekspresją PNX (Gottsch et al., 2004), które wysyłają swe projekcje do komórek gonadotropowych $(\mathrm{GnRH})$ w środkowym polu przedwzrokowym (Canteras et al., 1994; Simonian et al., 1999). PNX może zatem być nowym podwzgórzowym czynnikiem regulatorowym, który stymuluje działanie komórek gonadotropowych przysadki mózgowej. Hipotetycznie PNX może także aktywować neurony kisspeptynowe w sposób autokrynny $\mathrm{i} /$ lub przez połączenia $\mathrm{z}$ innymi komórkami z ekspresją PNX (Treen et al., 2016). Warto zauważyć, że większość neuronów nesfatynowych w jądrach podwzgórza szczura wykazuje ekspresję PNX, co może sugerować istnienie dotychczas nieznanych funkcjonalnych korelacji między neuropeptydami w mózgu (Pałasz et al., 2015). PNX jest ligandem metabotropowego receptora GPR173, manifestującego znaczną ekspresję zarówno w neuronach kisspeptynowych, jak i GnRH (Treen et al., 2016). GPR173, znany też jako SREB3, należy do superkonserwatywnej rodziny receptorów ulegających ekspresji w mózgu (SREB); został zidentyfikowany w ośrodkowym układzie nerwowym (OUN) oraz jajnikach i może odgrywać ważną rolę w regulacji osi podwzgórzowo-przysadkowo-gonadalnej (hypothalamic-pituitary-gonadal, HPG) (Matsumoto et al., 2005). Najnowsze badania sugerują, że receptor GPR173 w neuronach podwzgórzowych działa poprzez szlak kinazy cAMP/białka A przez czynniki transkrypcyjne CREB i prawdopodobnie C/EBP- $\beta$ i/lub Oct-1 w celu stymulacji ekspresji kisspeptyny-1 i GnRH (Treen et al., 2016).

Jiang i wsp. (2015a) w wartościowych badaniach wykazali, że PNX-14 działa jako silny czynnik przeciwlękowy u samców myszy przy podawaniu centralnym. Infuzja PNX-14 do komory bocznej albo przedniej części podwzgórza (anterior hypothalamic area, AHA) - ale nie do ciała migdałowatego - redukowała zachowania lękowe dorosłych zwierząt $w$ testach otwartego pola i uniesionego labiryntu krzyżowego (elevated plus maze, EPM). Co ważne, podanie selektywnego antagonisty receptora GnRH (cetroreliks) zniosło anksjolityczne działanie PNX-14. Z kolei blokada receptorów oksytocyny/wazopresyny przez atosiban nie zmieniła obserwowanego efektu. Dlatego należy przyjąć, że PNX-14 generuje niezależną od oksytocyny aktywność przeciwlękową poprzez stymulację układu sygnałowego GnRH w przednim podwzgórzu. Hofmann i wsp. (2017) jako pierwsi sprawdzili w badaniach klinicznych związek między obwodowym poziomem PNX a lękiem w dużej grupie $(N=68)$ otyłych, psychometrycznie zdiagnozowanych (Generalized Anxiety Disorder 7-item, GAD-7), hospitalizowanych mężczyzn. Poziomy depresyjności (depressiveness) i odczuwanego stresu mierzono odpowiednio za pomocą skali PHQ-9 (Perceived Health Questionnaire) 
anxiety states, while no relationships were observed with other parameters. Since the GnRH system may play a role in regulating learning processes and memory, a possible effect of PNX-14 in these phenomena was examined by means of novel object recognition (NOS) and object localisation recognition (OLR) tasks. Intriguingly, intraventricular injection of PNX-14 directly after testing significantly facilitated the process of memory creation in rats. Moreover, the ability to memorise was also reinforced under these experimental conditions. The same changes took place after a direct PNX-14 infusion to the hippocampus, yet they were inhibited by the selective GnRH antagonist (cetrorelix). Additionally, it was observed that central PNX-14 injection may reduce memory impairment induced by the amyloid- $\beta_{1-42}$ peptide and scopolamine, which suggests that PNX-14 may be effective as a potential medication in the Alzheimer's disease (AD) (Jiang et al., 2015b). In their recent study, Yuruyen et al. (2017) were the first to investigate the relationship between plasma PNX levels and subjective memory disorders in geriatric patients with a mild cognitive impairment (MCI). Interestingly, mean serum levels of PNX were negatively correlated with logical memory. Reduced plasma PNX levels should potentially be taken into consideration at the initial stages of MCI as a putative prognostic symptom. Unexpectedly, the PNX level did not correlate with cognitive functions in AD patients. So far, not much has been learnt about the role of PNX in higher functions of the brain, therefore the mechanism of its action should be a subject of further scientific investigation.

\section{NESFATIN-1 IN ANXIETY DISORDERS}

Nesfatin-1 is an 82-amino-acid molecule formed as a result of post-translational conversion of the precursor peptide NEFA/nucleobindin-2 (NUCB2). In the rat brain, neural populations with nesfatin-1 expression are mainly located in the hypothalamus and the brainstem (Goebel et al., 2009). Nesfatin-1 immunoreactivity was recently detected in the human hypothalamus (Psilopanagioti et al., 2019) as well as in the bed nucleus of the stria terminalis (BNST) (Pałasz et al., 2019).

A few recent studies suggest that acute restraint stress is one of the factors activating the expression of nesfatin-1 (Goebel et al., 2009; Stengel et al., 2010). Total adrenalectomy results in the increase in NUCB2 mRNA levels in the periventricular nucleus (PVN) of the hypothalamus, while an injection of nesfatin-1 to cerebral ventricles increases serum stress hormone levels: ACTH and corticosterone (Könczöl et al., 2010). Furthermore, nesfatin-1 seems to contribute to the general symptoms of stress and its injection to the brain ventricles of a rat increases blood pressure (Yosten and Samson, 2010). It is suggested that the hypertensive activity of centrally administered nesfa- i PSQ-20 (Perceived Stress Questionnaire). Stężenie PNX w osoczu było ujemnie skorelowane ze stanami lękowymi, nie wykryto natomiast żadnych związków z innymi parametrami. Ponieważ system GnRH może odgrywać rolę w regulacji procesów uczenia się i pamięci, efekt PNX-14 został zbadany za pomocą zadań rozpoznawania obiektów (novel object recognition, NOR) i rozpoznawania lokalizacji obiektów (object localisation recognition, OLR). Co ciekawe, iniekcja dokomorowa PNX-14 bezpośrednio po teście znacznie ułatwiła konsolidację pamięci u szczurów i wzmocniła zdolność do zapamiętywania. Analogiczne zmiany zaobserwowano po celowanej infuzji PNX-14 do hipokampa, ale były one hamowane przez selektywnego antagonistę GnRH (cetroreliks). Stwierdzono ponadto, że centralne podanie PNX-14 może zmniejszyć upośledzenie pamięci indukowane przez peptyd amyloidu- $\beta_{1-42}$ i skopolaminę, co sugeruje potencjał PNX-14 w terapii choroby Alzheimera (Alzheimer's disease, AD) (Jiang et al., 2015b). Najnowsze badania Yuruyena i wsp. (2017) jako pierwsze ujawniły związek między poziomem PNX w osoczu a subiektywnymi schorzeniami pamięci u pacjentów geriatrycznych $\mathrm{z}$ łagodnym upośledzeniem funkcji poznawczych (mild cognitive impairment, MCI). Co interesujące, średnie stężenie PNX w surowicy okazało się ujemnie skorelowane z pamięcią logiczną. Obniżony poziom PNX w osoczu powinien więc być potencjalnie brany pod uwagę w początkowych stadiach MCI jako symptom prognostyczny. Nieoczekiwanie poziom PNX nie korelował z funkcjami poznawczymi u pacjentów z AD. Niewiele wiadomo o znaczeniu PNX dla wyższych funkcji umysłowych, a zatem mechanizm owego działania powinien stać się przedmiotem przyszłych badań.

\section{NESFATYNA-1 W ZABURZENIACH LĘKOWYCH}

Nesfatyna-1 jest 82-aminokwasową cząsteczką powstałą w wyniku potranslacyjnej konwersji peptydu prekursorowego NEFA/nukleobindyny-2 (NUCB2). W mózgu szczura najsilniej zaznaczoną ekspresją nesfatyny-1 charakteryzują się neurony podwzgórza i pnia mózgu (Goebel et al., 2009), u ludzi neuropeptyd ten zlokalizowano dotychczas w podwzgórzu (Psilopanagioti et al., 2019) i jądrze łożowym blaszki krańcowej (bed nucleus of the stria terminalis, BNST) (Pałasz et al., 2019), strukturach związanych czynnościowo z mechanizmami stresu i lęku.

Kilka ostatnio przeprowadzonych badań sugeruje, że ostry ograniczony stres (acute restraint stress) jest jednym z czynników aktywujących ekspresję nesfatyny-1 (Goebel et al., 2009; Stengel et al., 2010). Całkowita adrenalektomia prowadzi do wzrostu poziomu mRNA NUCB2 w jądrze okołokomorowym (periventricular nucleus, $\mathrm{PVN}$ ) podwzgórza, natomiast wstrzyknięcie nesfatyny-1 do komór mózgu powoduje podniesienie poziomu hormonów stresu - stężenia ACTH i kortykosteronu w surowicy (Könczöl et al., 2010). Nesfatyna-1 wydaje się również przyczyniać do ogólnych objawów stresu, a jej wstrzyknięcie do bocznych komór mózgu szczura 
of the kidneys, in which the hypothalamic melanocortin pathways play a role (Tanida and Mori, 2011). Additionally, an increased expression of nesfatin-1 was observed in the nuclei raphes, locus coeruleus (LC) neurons and the Edinger-Westphal (EW) nucleus in rats exposed to various stressors, such as compression, abdominal surgery or administration of lipopolysaccharide. Nesfatin-1 activates stress-sensitive serotoninergic neurons in the raphe nuclei and noradrenergic neurons (LC), which, in turn, stimulate the CRF neurons in the PVN, and, as a consequence, activate the HPA axis. It is also known that nuclei raphes and LC are the key centres of the serotoninergic and noradrenergic system of signal transmission, and their dysfunctions are closely correlated with the pathogenesis of depression and anxiety disorders. At present, it seems probable that nesfatin-1 plays a hypothetical and nonspecific role in these mechanisms. Some authors suggest that nesfatin-1 induces anxiety reactions or fear and may also induce depressive reactions through the activation of melanocortin pathways, which results in the inhibition of GABAergic neurons or, alternatively, though hyperpolarisation of neuropeptide Y neurons (NPY) in the arcuate nucleus of the hypothalamus (Bali et al., 2014, Emmerzaal and Kozicz, 2013).

Behavioural studies on male rats show that nesfatin-1 injection into the cerebral ventricles caused a dosedependent reduction of the time spent in open arms in the elevated plus maze (EPM), which reflects its anxietyinducing effect, and increased the freezing time; however, it reduced food intake in unknown, potentially disturbing environmental conditions. The EPM test is one of the standard procedures to assess anxiety in rodents. It should be noted that nesfatin-1 did not affect any type of motor activity (Merali et al., 2008). Studies on rats using sucrose preference test revealed that nesfatin-1 administration may induce depression-like behaviour and reduce the open arms exploration in the elevated zero maze (EZM) test. This may suggest an increased anxiety score after treatment with this peptide. Of note, the changes did not occur in diet-induced obese (DIO) rats. Possibly, nesfatin-1 may induce anxiety only in normal weight animals (Kühne et al., 2018). Furthermore, long-term intraperitoneal administration of nesfatin-1 also promoted anxiety behaviour in male rats and reduced the level of brain-derived neurotrophic factor (BDNF) and phosphorylated extracellular signal-regulated kinases (ERK) in the prefrontal cortex and hippocampus (Ge et al., 2016). The above-presented results suggest a putative role of nesfatin-1 in the development of anxiety and anxiety-related reactions in animals. On the other hand, other studies revealed that rats exposed to acute, yet not chronic stress showed an increase both in the mRNA expression of NUCB2/nesfatin-1, and corticotropin-releasing hormone $(\mathrm{CRH})$ in the hypothalamus. Plasma levels of nesfatin-1 and corticosterone were also elevated (Xu et al., 2015). skutkuje wzrostem ciśnienia krwi (Yosten i Samson, 2010). Sugeruje się, że działanie hipertensyjne centralnie podawanej nesfatyny-1 jest także wynikiem stymulacji nerwów współczulnych nerek, w których pośredniczą podwzgórzowe szlaki melanokortynowe (Tanida i Mori, 2011). Zauważono ponadto zwiększoną ekspresję nesfatyny-1 w jądrach szwu, neuronach miejsca sinawego (łac. locus coeruleus, LC) i jądrze Edingera-Westphala (EW) u szczurów eksponowanych na działanie różnych czynników stresogennych, takich jak ucisk, operacja brzuszna i podawanie lipopolisacharydu. Nesfatyna-1 aktywuje wrażliwe na stres neurony serotoninergiczne w jądrze szwu i noradrenergiczne neurony LC, które z kolei stymulują neurony CRF w PVN i ostatecznie aktywują oś HPA. Wiadomo też, że jądra szwu i LC to kluczowe centra serotoninergicznego i noradrenergicznego systemu przekazywania sygnałów, a ich dysfunkcje są ściśle skorelowane z patogenezą depresji i zaburzeń lękowych. Wydaje się prawdopodobne, iż nesfatyna-1 odgrywa niespecyficzną rolę we wskazanych mechanizmach. Niektórzy autorzy sugerują, że nesfatyna-1 wywołuje reakcje lękowe i być może depresyjne poprzez aktywację szlaków melanokortyny, co przekłada się na hamowanie neuronów GABA-ergicznych, lub alternatywnie poprzez hiperpolaryzację neuronów neuropeptydu Y (neuropeptide Y, NPY) w jądrze łukowatym podwzgórza (Bali et al., 2014; Emmerzaal i Kozicz, 2013).

W badaniach behawioralnych na samcach szczurów wstrzyknięcie nesfatyny-1 do komór mózgowych w zależności od dawki skróciło czas spędzony w otwartych ramionach w teście uniesionego labiryntu krzyżowego (co jest odzwierciedleniem działania wywołującego lęk) i wydłużyło czas pozostawania w odrętwieniu (freezing), ale zmniejszyło spożycie pokarmu w nieznanych, potencjalnie niepokojących warunkach środowiska. Test EPM to jedna ze standardowych metod oceny lęku u gryzoni. Warto zauważyć, że nesfatyna-1 nie wpłynęła na żaden rodzaj aktywności ruchowej (Merali et al., 2008). Badania z zastosowaniem testu preferencji sacharozy (sucrose preference test) wykazały, iż podanie nesfatyny-1 może wywoływać u szczurów zachowania zbliżone do depresji, a nawet redukować penetrację otwartych ramion w teście EZM (elevated zero maze), co sugeruje zwiększony poziom lęku. U otyłych szczurów DIO (diet-induced obese) wymienione zmiany behawioralne nie występowały. Istnieje zatem domniemanie, iż nesfatyna-1 może indukować zachowania lękowe jedynie u zwierząt o normalnej masie ciała (Kühne et al., 2018). Długotrwałe dootrzewnowe podawanie nesfatyny-1 także sprzyjało zachowaniom lękowym u samców szczurów oraz zmniejszało poziom czynnika neurotroficznego pochodzenia mózgowego (brain-derived neurotrophic factor, BDNF) i fosforylowanych kinaz regulowanych sygnałami zewnątrzkomórkowymi ERK (extracellular signal-regulated kinases) w korze przedczołowej i hipokampie (Ge et al., 2016). Powyższe wyniki sugerują rolę nesfatyny-1 w powstawaniu lęku i reakcji związanych ze strachem u zwierząt. Inne badania wskazują z kolei, iż szczury narażone na ostry - ale nie chroniczny - stres wykazały wzrost zarówno 
It should be noted that the latest reports showed that the CRHR1 receptor may participate in the ERK1/2-dependent mechanism of nesfatin-1 action at the level of synaptic activity. The cells of human SH-SY5Y neuroblastoma cultured with nesfatin-1 presented an increased expression of both mRNA and the CRH protein, and also increased the levels of the $\mathrm{p}$-ERK1/2 protein and synapsin I. These effects were neutralised by CP376395, a selective antagonist of type 1 CRH receptor (CRHR1). Furthermore, PD98059, a specific p-ERK1/2 antagonist, selectively reversed the nesfatin-1-induced increase in synapsin I expression (Chen et al., 2018).

Higher serum levels of nesfatin-1 were observed in patients with a major depressive disorder (MDD) compared to healthy population (Ari et al., 2011). A highly specific positive correlation between plasma levels of nesfatin-1 and HAMD-17 (Hamilton Depression Rating Scale-17) score was also recently reported (Xu et al., 2018). Nesfatin-1 may therefore be a potential sensitive marker of moderate and severe depressive disorder (MSDD). This may be evidence for a bidirectional permeability of the blood-brain barrier for nesfatin-1. The mechanism of this phenomenon is unknown due to the lack of information about which neuronal populations expressing nesfatin-1 are responsible for increased neuropeptide secretion in MDD patients. Moreover, it cannot be ruled out that an additional source of circulating nesfatin-1 may be secondarily activated through some cells located outside the central nervous system. Bloem et al. (2012) showed that the mRNA expression of nesfatin-1/NUCB2 in a human EW nucleus was significantly increased in male suicidal victims, while this value was lower among females compared to the control group. It should be noted that the deceased individuals had no diagnostically-confirmed mental disorders. This intriguing discovery is the first to show the sex-related changes at the level of neuropeptides in the brain stem of suicide victims. Additionally, co-localisation of nesfatin-1/NUCB2 and the amphetamine-cocaine regulated transcript (CART) was observed in the EW nucleus, which suggests that there is a potential mutual dependence between both neuropeptides in the brain. Therefore, a possible role of nesfatin-1 signalling in the pathogenesis of depressive and anxiety behaviours should be considered. Despite a considerable development in scientific research on new neuropeptides, the relationship between anxiety and the activity of nesfatin-1 in humans has not been sufficiently studied. Clinical trials conducted by Gunay et al. (2012) showed decreased plasma levels of nesfatin-1 in male patients with generalised anxiety disorders compared to the control group. Another study was aimed at finding potential sex-related correlations between serum levels of nesfatin-1 and anxiety in obese patients, and their changes in the course of treatment. In women, nesfatin-1 level was positively correlated with anxiety states at the beginning and in the course of therapy. In contrast, a clear negative cor- ekspresji mRNA NUCB2/nesfatyny-1, jak i czynnika uwalniającego kortykotropinę (corticotropin-releasing hormone, $\mathrm{CRH}$ ) w podwzgórzu. Poziomy nesfatyny-1 w osoczu i kortykosteronu również były podwyższone (Xu et al., 2015).

Co warte odnotowania, zgodnie z ostatnimi doniesieniami receptor CRHR1 może uczestniczyć w zależnym od ERK1/2 mechanizmie działania nesfatyny-1 na poziomie transmisji synaptycznej. Komórki ludzkiego nerwiaka zarodkowego SH-SY5Y traktowane w hodowli nesfatyną-1 eksponowały podwyższoną ekspresję mRNA i białka CRH oraz zwiększały poziomy białka p-ERK1/2 i synapsyny I. Efekty te zostały zniesione przez CP376395, selektywnego antagonistę receptora CRH typu 1 (CRHR1). Ponadto specyficzny antagonista p-ERK1/2: PD98059 selektywnie odwracał indukowane przez nesfatynę-1 podwyższenie ekspresji synapsyny I (Chen et al., 2018).

$\mathrm{U}$ pacjentów z ciężką depresją (major depressive disorder, MDD) stwierdzono wyższy poziom nesfatyny-1 w surowicy w porównaniu $\mathrm{z}$ osobami zdrowymi (Ari et al., 2011). Zaobserwowano też pozytywną i wysoce specyficzną korelację między poziomem nesfatyny-1 w osoczu a wynikiem w skali HAMD-17 (Hamilton Depression Rating Scale-17) (Xu et al., 2018), co sugeruje, iż nowy neuropeptyd może być czułym markerem umiarkowanej i ciężkiej depresji (moderate and severe depressive disorder, MSDD). Może to być zarazem pośredni dowód na dwukierunkową przenikalność bariery krew-mózg dla nesfatyny-1. Mechanizm zjawiska jest nieznany ze względu na brak informacji, które populacje komórek mózgu są odpowiedzialne za zwiększone wydzielanie nesfatyny-1 u pacjentów z MDD. Ponadto nie można wykluczyć, że dodatkowe źródło cyrkulującej nesfatyny-1 jest wtórnie aktywowane przez niektóre komórki znajdujące się poza OUN. W badaniach Bloema i wsp. (2012) ekspresja mRNA nesfatyny-1/NUCB2 w ludzkim jądrze EW była znacząco podwyższona u mężczyzn zmarłych wskutek samobójstwa, podczas gdy wśród kobiet okazała się niższa w porównaniu z grupą kontrolną. Warto zauważyć, że osoby zmarłe nie miały potwierdzonych diagnostycznie zaburzeń psychicznych. To intrygujące odkrycie jest pierwszym, które pokazuje związane z płcią zmiany w poziomach neuropeptydów w pniu mózgu ofiar samobójstw. Stwierdzono także kolokalizację nesfatyny-1/NUCB2 i transkryptu regulowanego amfetaminą-kokainą (amphetamine-cocaine regulated transcript, CART) w jądrze EW, co sugeruje istnienie zależności między obydwoma neuropeptydami w mózgu. Należy zatem poddać pod dyskusję możliwą rolę sygnalizacji nesfatyny-1 w patogenezie zachowań depresyjnych i lękowych. Pomimo rozwoju badań nad nowymi neuropeptydami relacje między lękiem a działaniem nesfatyny-1 nie zostały wystarczająco przebadane u ludzi. Doświadczenia kliniczne przeprowadzone przez Gunaya i wsp. (2012) wykazały, że u pacjentów płci męskiej z uogólnionymi zaburzeniami lękowymi wystąpił spadek stężenia nesfatyny-1 w osoczu w porównaniu z grupą kontrolną. Inne badanie miało na celu znalezienie potencjalnych płciowozależnych korelacji między poziomem nesfatyny-1 a lękiem otyłych pacjentów i prześledzenie 
What is interesting, neither women nor men with anxiety symptoms showed significant fluctuations in plasma nesfatin-1 levels. This discovery suggests that women and men show an inverse relationship between NUCB2/nesfatin-1 and anxiety - women show a positive and men show a negative correlation; however, this relationship was not statistically significant in men in the initial phase of the therapy (Hofmann et al., 2015b). It should be noted that no correlation was found between serum nesfatin-1 levels and body mass index (BMI) (Hofmann et al., 2015a). The same scientific team had previously demonstrated a positive correlation between plasma nesfatin-1 levels and depression scores in obese women (Hofmann et al., 2013), which is in line with the evidence indicating an increased concentration of this neuropeptide in depressive patients with normal body weight (Ari et al., 2011).

Plasma nesfatin-1 levels were additionally measured in anorexia nervosa (AN) patients with low and high anxiety levels assessed with the GAD-7 protocol. Increased nesfatin-1 levels were observed in patients with a high anxiety level, which suggested a positive correlation between the GAD-7 score and neuropeptide concentration. Neither depressiveness (assessed with PHQ-20), perceived as stress (assessed with PSQ-9) nor eating disorders (assessed with EDI-2 - Eating Disorder Inventory-2) were correlated with nesfatin-1; however, they were increased in patients with a high anxiety level. To conclude, plasma nesfatin-1 levels correlate positively with perceptible anxiety without any relationships with eating disorder symptoms (Hofmann et al., 2015a). The aforementioned clinical results can be compared to the recent study of Lu et al. (2017) in which the authors showed sex-related changes in the levels of orexin A and OX2R in the brains of depressive patients. The immunoreactivity of orexin in the post mortem study was significantly increased in women with depression, but not in men as compared to healthy controls. Furthermore, a significant increase of OX2R was observed in the cortex of the anterior cingulate gyrus in men who had committed suicide (Lu et al., 2017). Due to highly anorexigenic properties of nesfatin-1, further research seems necessary to analyse its potential role in the pathogenesis of psychogenic eating disorders.

\section{THE MECHANISM OF NESFATIN-1 INVOLVEMENT IN ANXIETY REACTIONS}

Despite ongoing studies on the physiology of nesfatin-1, its role in the mechanism of anxiety has not been explained yet. Taking into account that hypothalamus, a structure particularly rich in peptide neurons, is the main area of nesfatin-1 action, a few hypotheses may be formulated. The first hypothesis suggests a direct effect of nesfatin-1 on the synthesis and release of CRF, which may control the activation of the HPA axis (Merali et al., 2008). The key position of CRF in the central pathways regulating anxiety, fear reactions and stress responses is generally accepted zmian stężenia neuropeptydu w toku leczenia. U kobiet na początku i podczas terapii poziom nesfatyny-1 w surowicy był dodatnio skorelowany z lękiem. U mężczyzn w trakcie leczenia wystąpiła wyraźna korelacja ujemna. Co ciekawe, ani $\mathrm{u}$ kobiet, ani u mężczyzn z objawami lękowymi nie stwierdzono istotnych fluktuacji poziomu nesfatyny-1 w osoczu. Obserwacja ta sugeruje, że kobiety i mężczyźni wykazują odmienny profil zależności między ekspresją NUCB2/nesfatyny-1 a poziomem lęku. U kobiet korelacja jest dodatnia, a u mężczyzn - ujemna, jednak u mężczyzn związek nie był statystycznie istotny w początkowej fazie leczenia (Hofmann et al., 2015b). Warto zauważyć, że nie znaleziono żadnej korelacji między stężeniem nesfatyny-1 w surowicy a wskaźnikiem masy ciała (body mass index, BMI) (Hofmann et al., 2015a). Ten sam zespół badawczy ujawnił wcześniej dodatnią korelację między stężeniem nesfatyny-1 w osoczu a skalą depresji (depression scores) u otyłych kobiet (Hofmann et al., 2013), co jest zgodne z dowodami wskazującymi na podwyższone stężenie neuropeptydu u pacjentów z prawidłową masą ciała manifestujących objawy depresji (Ari et al., 2011).

Stężenie nesfatyny-1 w osoczu mierzono również u osób $\mathrm{z}$ jadłowstrętem psychicznym (anorexia nervosa, AN) $\mathrm{z}$ niskimi i wysokimi poziomami lęku, ocenianymi zgodnie z protokołem GAD-7. U pacjentów z wysokim poziomem lęku stwierdzono podwyższone stężenie nesfatyny-1, sugerujące dodatnią korelację między wartością GAD-7 a stężeniem neuropeptydu. Ani depresyjność (oceniana kwestionariuszem PSQ-20) postrzegana jako stres (oceniany kwestionariuszem PHQ-9), ani zaburzenia odżywiania (oceniane kwestionariuszem EDI-2 - Eating Disorder Inventory-2) nie były związane $\mathrm{z}$ nesfatyną-1, ale u pacjentów z wysokim poziomem lęku ich wskaźniki okazały się podwyższone. Podsumowując: stężenia nesfatyny-1 w osoczu dodatnio korelują z odczuwanym lękiem bez jakichkolwiek powiązań z objawami zaburzeń odżywiania (Hofmann et al., 2015a). Przedstawione wyżej wyniki kliniczne można porównać z niedawnym badaniem Lu i wsp. (2017), które wykazało zależne od płci zmiany poziomów oreksyny A i OX2R w mózgu pacjentów z depresją. Immunoreaktywność oreksyny w badaniu post mortem była znacznie podwyższona $\mathrm{u}$ kobiet $\mathrm{w}$ depresji, ale nie u mężczyzn. Ponadto w korze przedniego zakrętu obręczy u mężczyzn, którzy popełnili samobójstwo, stwierdzono znaczny wzrost OX2R (Lu et al., 2017). Ze względu na wysoce anoreksygenne właściwości nesfatyny-1 uzasadnione wydaje się prowadzenie dalszych badań nad potencjalną rolą nowego neuropeptydu w patogenezie psychogennych zaburzeń odżywiania.

\section{POTENCJALNY MECHANIZM ROLI NESFATYNY-1 W REAKCJACH LĘKOWYCH}

Pomimo trwających badań nad fizjologią nesfatyny-1 jej rola w mechanizmie lęku nie została jeszcze wyjaśniona. Ponieważ jednak podwzgórze, struktura szczególnie bogata w neurony peptydowe, jest głównym obszarem działania nesfatyny-1, można sformułować kilka hipotez. Pierwsza sugeruje 
(Borrow et al., 2016; Koob and Heinrichs, 1999). Patients suffering from AN present with both extremely reduced food intake and increased physical activity. In accordance with the model of this anxiety-related disorder, these patients manifest significantly increased release of $\mathrm{CRH}$ and glucocorticoids in the course of a meal, which reflects the activation of the HPA axis. Moreover, food intake stimulates cholecystokinin (CCK) secretion, generating the sense of satiety and, at the same time, activating $\mathrm{CRH}$, which leads to increased anxiety responses and inhibits eating behaviour. Considering both, high co-expression of CRF-nesfatin-1 and numerous paracrine connections between nesfatin-1 cells and CRF, this possibility seems to be particularly credible. Molecular trials also prove that the PVN neurons release nesfatin-1 from the secretory vesicles (Maejima et al., 2009). The cells expressing CRF may be sensitive to nesfatin-1; however, its receptor is still unknown, therefore the precise mechanism of nesfatin-1 action has not been explained yet. It should be considered that the CRF neurons in the PVN differ both in terms of their response to the paracrine release of the neuropeptide and their effects on target neuron populations (Dabrowska et al., 2013). The potential anxiogenic effect of nesfatin-1 may result from the putative stimulation of the metabotropic receptor and activation of the intracellular signalling cascade, which facilitates CRF release to the median eminence. An elevated calcium level in the CRF neurons isolated from the rat's PVN after exposure to nesfatin-1 confirms this hypothesis. Furthermore, central nesfatin-1 injection in the absence of other stressors increases the level of circulating ACTH and corticosterone (Yoshida et al., 2010). Interestingly, nesfatin-1-sensitive noradrenergic and serotoninergic neurons in the locus coeruleus and dorsal raphe nuclei send their projections to the CRF neurons in the PVN, which may stimulate the HPA axis in an alternative way (Cunningham and Sawchenko, 1988). To conclude, nesfatin-1 is involved in generating anxiety, and the nesfatinergic neurons located in both the hypothalamus and the brainstem may invoke responses to fear through the stimulation of CRF and aminergic neurons at an early stage. The ultimate, physiological outcome of neuropeptide activity depends on the type of the activated CRF receptor. CRF binding to the CRF1 receptor has an anxiogenic effect, while the activation of the CRF2 receptor elicits an anxiety-relieving response (Kormos and Gaszner, 2013). Importantly, some hypothalamic neurons located in the arcuate (ARC) and paraventricular (PVN) nuclei synthesize urocortin 2 (UCN2) as a strongly anxiogenic neuropeptide, which binds selectively to the CRF2 receptor (Reyes et al., 2001). On the other hand, anxiolytic expression of urocortin 3 (UCN3) in the hypothalamus was also observed ( $\mathrm{Li}$ et al., 2002). Therefore, it cannot be ruled out that nesfatin-1 may also affect the synthesis and release of both urocortins at the level of hypothalamic circuits. And again, it cannot be ruled out that nes- bezpośredni wpływ nesfatyny-1 na syntezę i uwalnianie CRF, który może kontrolować aktywację osi HPA (Merali et al., 2008). Kluczowa pozycja CRF w centralnych szlakach regulujących lęk, reakcje strachu i reakcje odpowiedzi na stres jest ogólnie akceptowana (Borrow et al., 2016; Koob i Heinrichs, 1999). Pacjenci cierpiący na AN wykazują zarówno skrajnie zmniejszone przyjmowanie pokarmu, jak i zwiększoną aktywność fizyczną. Zgodnie z modelem zaburzenia związanym z lękiem u osób z AN występuje znacznie wzmożone uwalnianie CRH i glikokortykosteroidów podczas jedzenia, co odzwierciedla aktywację osi HPA. Co więcej, przyjmowanie pokarmu stymuluje wydzielanie cholecystokininy (CCK), generując uczucie sytości i aktywując uwalnianie $\mathrm{CRH}$, które skutkuje podwyższeniem odpowiedzi lękowych i hamuje jedzenie. Biorąc pod uwagę zarówno wysoką koekspresję CRF i nesfatyny-1, jak i liczne połączenia parakrynne między komórkami nesfatyny-1 i CRF, przedstawiona hipoteza wydaje się szczególnie wiarygodna. Badania molekularne dowodzą również, że neurony PVN uwalniają nesfatynę-1 z pęcherzyków wydzielniczych (Maejima et al., 2009). Komórki wykazujące ekspresję CRF mogą być wrażliwe na nesfatynę-1, jednak receptor wciąż jest nieznany, co nie pozwala dokładnie wyjaśnić mechanizmu działania nesfatyny-1. Należy uwzględnić fakt, że neurony CRF w PVN różnią się odpowiedzią na uwalnianie parakrynne neuropeptydu i wpływem na docelowe populacje neuronów (Dabrowska et al., 2013). Potencjalny efekt anksjogenny nesfatyny-1 może być wynikiem domniemanej stymulacji receptora sprzężonego z białkiem G i aktywacji wewnątrzkomórkowej kaskady sygnałowej, która pozwala na uwolnienie CRF do wyniosłości pośrodkowej. Podwyższony poziom wapnia w neuronach CRF izolowanych ze szczurzego PVN po ekspozycji na nesfatynę-1 potwierdza tę hipotezę. Ponadto centralne wstrzyknięcie nesfatyny-1 bez dodatkowych bodźców stresogennych skutkuje wzrostem poziomu krążącego ACTH i kortykosteronu (Yoshida et al., 2010). Co ciekawe, wrażliwe na nesfatynę-1 neurony noradrenergiczne i serotoninergiczne w miejscu sinawym i grzbietowym jądrze szwu przesyłają swoje projekcje do neuronów CRF w PVN, które w sposób alternatywny mogą stymulować oś HPA (Cunningham i Sawchenko, 1988). Podsumowując: nesfatyna-1 jest zaangażowana $\mathrm{w}$ generowanie lęku, a neurony nesfatynergiczne zarówno w podwzgórzu, jak i w pniu mózgu mogą we wczesnej fazie wywoływać odpowiedź na strach poprzez stymulację CRF i neuronów aminergicznych. Ostateczny fizjologiczny wynik działania neuropeptydu zależy od typu aktywowanego receptora CRF. Wiązanie CRF z receptorem CRF1 ma działanie anksjogenne, podczas gdy aktywacja receptora CRF2 prowadzi do odpowiedzi przeciwlękowych (Kormos i Gaszner, 2013). Co ważne, niektóre neurony podwzgórzowe zlokalizowane w jądrze łukowatym i przykomorowym syntetyzują urokortynę 2 (UCN2), silnie działający neuroteptyd anksjogenny, który selektywnie wiąże się z receptorem CRF2 (Reyes et al., 2001). Stwierdzono również anksjolityczną ekspresję urokortyny 3 (UCN3) w podwzgórzu (Li et al., 2002). Nie można zatem wykluczyć, że nesfatyna-1 wpływa na syntezę 
Additionally, nesfatin-1 signalling may also play a role in the mechanism of visceral hypersensitivity through the modulation of the CRF/CRF1 system (Jia et al., 2013). The effect of nesfatin-1 on the CRF signalling may also take place outside the hypothalamus, in the amygdala in particular, where a clear expression of NUCB2 takes place (Goebel et al., 2009). There is a hypothesis suggesting that stress-related anxiety can be regulated by various groups of CRF neurons in the amygdala complex and BNST (Walker et al., 2009). Nesfatin-1 might be co-expressed with CRF in this region. Regev et al. (2011) showed that CRF overexpression in the central nucleus of the amygdala (CeA) reduced stress-dependent anxiety symptoms in rats. On the other hand, other studies revealed an elevated anxiety level in rats with CRF overexpression in CeA and increased expression in the PVN. Nesfatin-1 released in the CeA is likely to affect the anxiety response through the modulation of CRF exocytosis from local neurons. The latest study involving the retrograde tracing showed that nesfatin-1 neurons in the CA1 region of the hippocampus send stimulatory projections to the hypothalamus. Furthermore, electrical activation of these cells induces neuronal stimulation. Nesfatin-1 injection to the ventromedial hypothalamus $(\mathrm{VMH})$ reduces the activity of neurons responding to abdominal distension through the modulation of the CRF signalling circuit (Feng et al., 2017). A hypothesis may be therefore formulated that nesfatin-1 signalling may link the hypothalamic and limbic structures responsible for anxiety reactions and eating behaviours. The pathway of the brain-derived neurotrophic factor (BDNF) may also be a potential target of nesfatin-1 activity in the central mechanisms of anxiety. As already mentioned before, long-term intraperitoneal injection of nesfatin-1 reduced BDNF expression in the hippocampus and prefrontal cortex in a rat and induced anxiety behaviours (Ge et al., 2016).

\section{CONCLUSIONS}

Recently identified neuropeptides - nesfatin-1 and phoenixin - are characterised by a wide spectrum of sex-dependent regulatory activity in the brain. It is reasonable to assume, based on the collected evidence, that they are novel, potentially significant factors involved in the pathogenesis of a few mental disorders. Therefore, it should not be ruled out that a targeted pharmacomodulation of the signalling based on these neuropeptides may be potentially helpful in the future treatment of anxiety disorders. Undoubtedly, more advanced studies in this field are needed. Although the outcomes of some basic and clinical studies seem to be encouraging, any possible applications of the aforementioned neuropeptides, as well as their agonists and antagonists still remain in the zone of speculation. Nevertheless, intensive search for selective modulators of their known receptors may help open a promising chapter in the pharmacotherapy of anxiety. i uwalnianie obu urokortyn w podwzgórzu. Istnieje możliwość, iż nesfatyna-1 jest alternatywnym ligandem receptorów CRF. Dodatkowo sygnalizacja nesfatynowa może odgrywać rolę w mechanizmie nadwrażliwości trzewnej poprzez modulację systemu CRF/CRF1 (Jia et al., 2013). Wpływ nesfatyny-1 na sygnalizację CRF może też występować poza podwzgórzem, szczególnie w ciele migdałowatym, gdzie dochodzi do wyraźnej ekspresji NUCB2 (Goebel et al., 2009). Istnieje hipoteza sugerująca, że lęk powiązany ze stresem może być regulowany przez różne grupy neuronów CRF w kompleksie migdałowatym i BNST (Walker et al., 2009). Nesfatyna-1 może wykazywać koekspresję z CRF w neuronach wskazanej wyżej okolicy. Regev i wsp. (2011) wykazali, że nadekspresja CRF w centralnym jądrze migdałowatym (central nucleus of the amygdala, CeA) powodowała u szczurów redukcję objawów lękowych zależnych od stresu. W innych badaniach stwierdzono z kolei podwyższony poziom lęku u szczurów z nadmierną ekspresją CRF w CeA i zwiększoną w PVN. Nesfatyna-1 uwalniana w CeA prawdopodobnie może wpływać na odpowiedź lękową przez modulację egzocytozy CRF $\mathrm{z}$ lokalnych neuronów. Badania strukturalne z wykorzystaniem znakowania wstecznego (retrograde tracing) wykazały, że neurony nesfatynowe w regionie CA1 hipokampa wysyłają pobudzające projekcje do podwzgórza. Stymulacja elektryczna skutkuje pobudzeniem neuronów (ventromedial hypothalamus, VMH). Wstrzyknięcie nesfatyny-1 do VMH zmniejsza aktywność neuronów reagujących na rozciągnięcie ściany żołądka poprzez modulację szlaku sygnałowego CRF (Feng et al., 2017). Można zatem sformułować hipotezę, że sygnalizacja nesfatyny-1 lączy struktury podwzgórzowe i limbiczne odpowiedzialne za reakcje lękowe i zachowania pokarmowe. Szlak czynnika neurotroficznego pochodzenia mózgowego (brain-derived neurotrophic factor, BDNF) może być też celem działania nesfatyny-1 w centralnych mechanizmach lękowych. Jak wspomniano wcześniej, długoterminowe dootrzewnowe wstrzyknięcie nesfatyny-1 zmniejszało ekspresję białka BNDF w hipokampie szczura i korze przedczołowej oraz wywoływało zachowania lękowe (Ge et al., 2016).

\section{PODSUMOWANIE}

Ostatnio zidentyfikowane neuropeptydy - feniksyna i nesfatyna-1 - charakteryzują się szerokim zakresem płciowozależnej aktywności regulatorowej w mózgu. Zgromadzono już dane pozwalające uznać nowe neuropeptydy za potencjalnie ważne czynniki zaangażowane w patogenezę kilku zaburzeń psychicznych. Niewykluczone zatem, że celowana farmakomodulacja sygnalizacji opartej na feniksynie i nesfatynie-1 może być pomocna w przyszłym leczeniu zaburzeń lękowych. Chociaż wyniki szeregu badań podstawowych i klinicznych wydają się perspektywiczne, wszelkie potencjalne zastosowania wymienionych neuropeptydów, a także ich agonistów i antagonistów wciąż pozostają w obszarze spekulacji. Niemniej intensywne poszukiwanie selektywnych modulatorów znanych receptorów może się przyczynić do otwarcia obiecującego rozdziału w farmakoterapii lęku. 


\section{Conflict of interest}

The authors do not declare any financial or personal links with other persons or organisations that might adversely affect the content of the publication or claim any right to the publication.

\section{Konflikt interesów}

Autorzy nie zgłaszaja żadnych finansowych ani osobistych powiązań z innymi osobami lub organizacjami, które moglyby negatywnie wplynać na treść publikacji oraz rościć sobie prawo do tej publikacji.

Hofmann T, Stengel A, Ahnis A et al.: NUCB2/nesfatin-1 is associated with elevated scores of anxiety in female obese patients. Psychoneuroendocrinology 2013; 38: 2502-2510.

Hofmann T, Weibert E, Ahnis A et al.: Phoenixin is negatively associated with anxiety in obese men. Peptides 2017; 88: 32-36.

Jalewa J, Wong-Lin K, McGinnity TM et al.: Increased number of orexin/hypocretin neurons with high and prolonged external stress-induced depression. Behav Brain Res 2014; 272: 196-204.

Jia FY, Li XL, Li TN et al.: Role of nesfatin-1 in a rat model of visceral hypersensitivity. World J Gastroenterol 2013; 19: 3487-3493.

Jiang JH, He Z, Peng YL et al.: Effects of phoenixin-14 on anxiolyticlike behavior in mice. Behav Brain Res 2015a; 286: 39-48.

Jiang JH, He Z, Peng YL et al.: Phoenixin-14 enhances memory and mitigates memory impairment induced by $\mathrm{A}_{1-42}$ and scopolamine in mice. Brain Res 2015b; 1629: 298-308.

Johnson PL, Truitt W, Fitz SD et al.: A key role for orexin in panic anxiety. Nat Med 2010; 16: 111-115.

Jungling K, Seidenbecher T, Sosulina L et al.: Neuropeptide S-mediated control of fear expression and extinction: role of intercalated GABAergic neurons in the amygdala. Neuron 2008; 59: 298-310.

Jurek B, Slattery DA, Hiraoka Y et al.: Oxytocin regulates stressinduced Crf gene transcription through CREB-regulated transcription coactivator 3. J Neurosci 2015; 35: 12248-12260.

Knepel W, Homolka L, Vlaskovska M et al.: Stimulation of adrenocorticotropin/ $\beta$-endorphin release by synthetic ovine corticotropin-releasing factor in vitro. Enhancement by various vasopressin analogs. Neuroendocrinology 1984; 38: 344-350.

Könczöl K, Bodnár I, Zelena D et al.: Nesfatin-1/NUCB2 may participate in the activation of the hypothalamic-pituitary-adrenal axis in rats. Neurochem Int 2010; 57: 189-197.

Koob GF, Heinrichs SC: A role for corticotropin releasing factor and urocortin in behavioral responses to stressors. Brain Res 1999; 848: 141-152.

Kormos V, Gaszner B: Role of neuropeptides in anxiety, stress, and depression: from animals to humans. Neuropeptides 2013; 47: 401-419.

Kühne SG, Schalla MA, Friedrich T et al.: Nesfatin- $1_{30-59}$ injected intracerebroventricularly increases anxiety, depression-like behavior, and anhedonia in normal weight rats. Nutrients 2018; 10. pii: E1889.

Kumsta R, Chen FS, Pape HC et al.: Neuropeptide S receptor gene is associated with cortisol responses to social stress in humans. Biol Psychol 2013; 93: 304-307.

Li C, Vaughan J, Sawchenko PE et al.: Urocortin III-immunoreactive projections in rat brain: partial overlap with sites of type 2 corticotrophin-releasing factor receptor expression. J Neurosci 2002; 22 : 991-1001.

Lu J, Zhao J, Balesar R et al.: Sexually dimorphic changes of hypocretin (orexin) in depression. EBioMedicine 2017; 18: 311-319.

Lucas N, Legrand R, Ouelaa W et al.: Effects of rabbit anti- $\alpha-$ melanocyte-stimulating hormone ( $\alpha-\mathrm{MSH})$ immunoglobulins on a-MSH signaling related to food intake control. Neuropeptides 2014; 48: 21-27.

Lyu RM, Huang XF, Zhang Y et al.: Phoenixin: a novel peptide in rodent sensory ganglia. Neuroscience 2013; 250: 622-631.

Maejima Y, Sedbazar U, Suyama S et al.: Nesfatin-1-regulated oxytocinergic signaling in the paraventricular nucleus causes anorexia through a leptin-independent melanocortin pathway. Cell Metab 2009; 10: 355-365.

Matsumoto M, Beltaifa S, Weickert CS et al.: A conserved mRNA expression profile of SREB2 (GPR85) in adult human, monkey, and rat forebrain. Brain Res Mol Brain Res 2005; 138: 58-69.
Hofmann T, Ahnis A, Elbelt U et al.: NUCB2/nesfatin-1 is associated with elevated levels of anxiety in anorexia nervosa. PLoS One 2015a; 10: e0132058.

Hofmann T, Elbelt U, Ahnis A et al.: Sex-specific regulation of NUCB2/nesfatin-1: differential implication in anxiety in obese men and women. Psychoneuroendocrinology 2015b; 60: 130-137. 
Merali Z, Cayer C, Kent P et al.: Nesfatin-1 increases anxiety- and fearrelated behaviors in the rat. Psychopharmacology (Berl) 2008; 201: $115-123$.

Pałasz A, Bogus K, Suszka-Świtek A et al.: The first identification of nesfatin-1-expressing neurons in the human bed nucleus of the stria terminalis. J Neural Transm (Vienna) 2019; 126: 349-355.

Pałasz A, Rojczyk E, Bogus K et al.: The novel neuropeptide phoenixin is highly co-expressed with nesfatin-1 in the rat hypothalamus, an immunohistochemical study. Neurosci Lett 2015; 592 $17-21$.

Psilopanagioti A, Nikou S, Papadaki H: Nucleobindin-2/nesfatin-1 in the human hypothalamus is reduced in obese subjects and colocalizes with oxytocin, vasopressin, melanin-concentrating hormone, and cocaine- and amphetamine-regulated transcript. Neuroendocrinology 2019; 108: 190-200.

Regev L, Neufeld-Cohen A, Tsoory $M$ et al.: Prolonged and site-specific over-expression of corticotropin-releasing factor reveals differential roles for extended amygdala nuclei in emotional regulation. Mol Psychiatry 2011; 16: 714-728.

Reyes TM, Lewis K, Perrin MH et al.: Urocortin II: a member of the corticotropin-releasing factor (CRF) neuropeptide family that is selectively bound by type 2 CRF receptors. Proc Natl Acad Sci U S A 2001; 98: 2843-2848.

Si W, Aluisio L, Okamura N et al.: Neuropeptide S stimulates dopaminergic neurotransmission in the medial prefrontal cortex. J Neurochem 2010; 115: 475-482.

Simonian SX, Spratt DP, Herbison AE: Identification and characterization of estrogen receptor alpha-containing neurons projecting to the vicinity of the gonadotropin-releasing hormone perikarya in the rostral preoptic area of the rat. J Comp Neurol 1999; 411: 346-358.

Slattery DA, Naik RR, Grund T et al.: Selective breeding for high anxiety introduces a synonymous SNP that increases neuropeptide S receptor activity. J Neurosci 2015; 35: 4599-4613.
Stein DJ, Scott KM, de Jonge P et al.: Epidemiology of anxiety disorders: from surveys to nosology and back. Dialogues Clin Neurosci 2017; 19: 127-136.

Stengel A, Goebel M, Taché Y: Nesfatin-1: a novel inhibitory regulator of food intake and body weight. Obes Rev 2010; 12: 261-271.

Tanida M, Mori M: Nesfatin-1 stimulates renal sympathetic nerve activity in rats. Neuroreport 2011; 22: 309-312.

Treen AK, Luo V, Belsham DD: Phoenixin activates immortalized $\mathrm{GnRH}$ and kisspeptin neurons through the novel receptor GPR173. Mol Endocrinol 2016; 30: 872-888.

Walker DL, Miles LA, Davis M: Selective participation of the bed nucleus of the stria terminalis and CRF in sustained anxiety-like versus phasic fear-like responses. Prog Neuropsychopharmacol Biol Psychiatry 2009; 33: 1291-1308.

Xu YY, Ge JF, Liang J et al.: Nesfatin-1 and cortisol: potential novel diagnostic biomarkers in moderate and severe depressive disorder. Psychol Res Behav Manag 2018; 11: 495-502.

Xu YY, Ge JF, Qin G et al.: Acute, but not chronic, stress increased the plasma concentration and hypothalamic mRNA expression of NUCB2/nesfatin-1 in rats. Neuropeptides 2015; 54: 47-53.

Yoshida N, Maejima Y, Sedbazar U et al.: Stressor-responsive central nesfatin-1 activates corticotropin-releasing hormone, noradrenaline and serotonin neurons and evokes hypothalamic-pituitaryadrenal axis. Aging (Albany NY) 2010; 2: 775-784.

Yosten GLC, Samson WK: The anorexigenic and hypertensive effects of nesfatin-1 are reversed by pretreatment with an oxytocin receptor antagonist. Am J Physiol Regul Integr Comp Physiol 2010; 298: R1642-R1647.

Yosten GL, Lyu RM, Hsueh AJ et al.: A novel reproductive peptide, phoenixin. J Neuroendocrinol 2013; 25: 206-215.

Yuruyen M, Gultekin G, Batun GC et al.: Does plasma phoenixin level associate with cognition? Comparison between subjective memory complaint, mild cognitive impairment, and mild Alzheimer's disease. Int Psychogeriatr 2017: 1-8. 